\title{
Environmental Effects of Reducing Land Fragmentation in Land Consolidation at West Roztocze at the Slope Scale
}

\author{
Roman Rybicki ${ }^{1}$ \\ 1 Department of Environmental Engineering and Geodesy, University of Life Sciences in Lublin, \\ ul. Leszczyńskiego 7, 20-069 Lublin, Poland \\ e-mail: roman.rybicki@up.lublin.pl
}

\begin{abstract}
The paper presents the ecological effects of land consolidation carried out in upland loess areas. The design of a large plot of land on a slope with a gradient of up to $18 \%$ and its impact on the intensity of water erosion were investigated. The analyzed plot was created by consolidation 12 smaller plots. Before the consolidation, all plots had a cross-slope layout and direction of agrotechnical operations. Exactly the same arrangement remained after the consolidation. The WEPP simulation model was used for the comparison of the pre-consolidation and postconsolidation state. The amount of soil loss and sediment yield was estimated under different scenarios of slope management. It was found that after consolidation (creation of a plot with the width of more than $130 \mathrm{~m}$ ), as a result of removing of terraces and sodded cross-slope scarps, the intensity of erosion increased many times. In order to restore the anti-erosion effect of cross-slope cultivation on such a slope without increasing the difficulties of agrotechnics, it is necessary to restore the sodded scarps that existed before consolidation. The simulation results show that the scarps should be located transversely to the slope (along the plot) in the middle and lower parts of the slope, in the place of the highest inclination. As advantage of the consolidation project was considered the elimination of longitudinal balks which were focuses of linear erosion on the slope.
\end{abstract}

Keywords: land consolidation, water erosion, soil loss, loess upland areas

\section{INTRODUCTION}

The economic conditions of Poland, as well as strong international competition in agriculture, force the agricultural producers to obtain the products that are relatively cheaper and, at the same time, of better quality. In order to remedy this, the rural areas require numerous changes in terms of agricultural production and farm organization. Particularly great needs arise in the scope of organizing the optimal layouts for agriculture, where the land is as close to the farm as possible, in the largest possible shaped plots of land [Woch 2006].

A tool enabling the improvement and rationalization of the agricultural production space, facilitating the management of agriculture and forestry, are agricultural management works, in particular land consolidation [Sayilan 2014; Sobolewska-Mikulska and Pułecka 2007]. The main purpose of these measures is to create more favorable conditions for farming by improving the area structure of farms, recovering new arable land by eliminating unnecessary balks, scarps, dirt roads and fallow land, rational shaping of land layouts, as well as adjusting the real estate boundaries to the system of water facilities, roads (including highways) and the relief [Journal of Laws 11, item 80]. The advantages of building a fully-fledged real estate cadaster are also important [Leń and Król 2016; Moravcova et al. 2017]. The agricultural management works are designed to nurture, raise, and, if necessary, restore soil production capacity, take care of the aesthetics of the rural landscape and adapt the rural areas to modern forms of farming [Przegon 2007; Sobolewska-Mikulska and Pułecka 2007]. Therefore, these measures are one of the most complex, costly and responsible works, generating measurable benefits in the development of the rural areas over 
a longer time horizon [Pašakarnis and Maliene 2010; Przegon 2007].

The upland areas located in the south-eastern part of Poland, due to the high production potential of soils, have been included to the areas of intensive agricultural development [Kondracki 2002]. However, there are many negative factors limiting the agricultural production in this area. The most important ones include the surface and ravine water erosion with all its effects. In addition, these areas have long been characterized by high population density, which results in a large fragmentation and dispersion of land of individual farms, additionally hindering management and reducing its efficiency. For this reason, there is a great need for consolidation works also in the eroded areas. Due to the varied relief and micro relief of the terrain, i.e. the presence of valleys and slopes of various exposures, suffusion dips and other post-erosion wastelands, it may be extremely difficult to prepare a land consolidation project [Józefaciuk et al. 1991]. At the same time, the fragmentation of the land and the related dense structure of balks and scarps, trees, sodding, and mosaic of crops mean that the occurrence and intensity of water erosion is limited [Koreleski 1991]. If consolidation works are carried out in a classic way, without taking into account the principles of anti-erosion protection, the erosion processes are triggered, including surface washes of soil and the formation of gullies [Józefaciuk et al. 1991; Koreleski 1991; Uiszczak 1960]. Similar conclusions are put forward in foreign literature [Bucher and Demuth 1986; Bronstert et al. 1995; Chartin et al. 2013; Evrard et al. 2010; Van Dijk 2007]. The most intense erosive processes occur in the first years after the end of the consolidation process [Uiszczak 1960; Evrard et al. 2010]. This is due to many factors, in particular:

- creation of larger plots, rarely in a transverse arrangement

- liquidation of almost all balks and scarps, which function as anti-erosion forms

- creating of a new network of agricultural roads without their hardening and anti-erosion protection.

In the conducted classical consolidation, the losses caused by erosive soil degradation may often exceed the effects of consolidation resulting from the improvement of land layout [Józefaciuk et al. 1991; Koreleski 1991; Shuai et al. 2011]. Therefore, in the upland loess areas, land consolidation should be performed only as comprehensive consolidation, taking into account the principles of anti-erosion melioration [Woch and Józefaciuk 1999], especially that the use of special preventive and reclamation measures during consolidation, even in large areas, is associated with a relatively small, additional expenditure of effort and resources [Józefaciuk et al. 1999; Nowocień 2006].

The main goals of the implemented anti-erosion melioration in complex consolidation are:

- limiting the occurrence and reducing the intensity of erosive processes,

- maintaining the productive potential of soils and preventing its reduction,

- extending the water cycle in the landscape and counteracting the deformational changes in hydrography and hydrology of river courses,

- improvement of the eco-technical land use conditions, including reclamation of devastated land [Kadlec et al. 2014; Konečna et al. 2011; Lisec and Pintar 2005; Nowocień 2006; Podhrázská and Jeníčková 2011].

Therefore, the consolidation of eroded areas requires a specialized approach and a series of works, divided into several stages (analysis, conceptual and design phase, task implementation) [Józefaciuk et al. 1999; Nowocień 2006].

The concept of such comprehensive mergers developed and implemented by IUNG in Puławy showed that in addition to the positive economic and agricultural effects that are achieved during classic mergers, it is also possible to obtain positive environmental and ecological effects.

Despite the positive results of the conceptual work, the Regional Bureau of Geodesy in Lublin does not currently perform comprehensive consolidations, and classic consolidation works are concentrated mainly in flat areas (counties: Łęczna, Łuków, Lubartów, Włodawa, Chełm and Krasnystaw). Nevertheless, several objects located in the high differentiated relief areas were also merged. One of them is Latyczyn in West Roztocze.

Due to the risk of water erosion, the assumptions for the consolidation project, apart from the classic ones, also included the anti-erosion measures. In addition to the strengthening of agricultural transport roads, these measures also included the adaptation of new boundaries of plots to relief or in the case of the correct layout - leaving it unchanged [Jabłoński 2012, Rybicki 2017]. 
The aim of the study is to evaluate the environmental effect of consolidation of 12 small plots located on a slope with a gradient of up to $18 \%$ into one large plot.

From an agricultural point of view, the creation of large plots of land during land consolidation is advisable. This facilitates the agrotechnical operations and contributes to the reduction of labor consumption and agricultural production inputs. However, in loess highlands, due to the type of soil and topography, the designed plots of large areas should be assessed in terms of the water erosion risk.

\section{CHARACTERISTICS OF THE FACILITY AND METHODS}

The study area - Latyczyn village (with an area of $972.85 \mathrm{ha}$ ) is located in the Radecznica municipality, Zamość district. Land consolidation was conducted in the years 2012-2014. The object is located in the area of the Szczebrzeszyn Landscape Park in West Roztocze and should be considered as typical for this region. A very diverse relief, reaching the height differences of $100 \mathrm{~m}$, is also typical. Hills are crossed by numerous well-developed gullies. Over $80 \%$ of the area is occupied by the deep loess soils. Because of the type of the soils and the slope of land, which exceeds even $20 \%$, as well as the type of climate (cold winters with the rapid thawing of snow and warm dry summers with heavy rain), about $25 \%$ of the area is threatened by medium to strong grade of water erosion [Rybicki 2017].

For this reason, the surveyors-designers, while improving the spatial and economic parameters of land, took into account the need to preserve the existing contour layout of plots and to leave, if possible, high balks with shrubs or shelterbelts intact [Jabłoński 2012]. Where the layout of the parcels was disadvantageous (longitudinal), it was changed into a cross-slope (adapted to the principle of anti-erosion land development) [Rybicki 2017].

In the investigated village, as a result of consolidation, several quite large plots of arable land were designed, including those located on steep slopes. Most of them have such a system that allows or even forces the cross-slope cultivation. One of such plots is the subject of research in this work.
On the studied part of the slope, all the plots before consolidation had the cross-slope arrangement with the same direction of agrotechnical operations (Fig. 1). The same layout remained after consolidation. Merging several plots into one large, as a rule, is associated with the removal of balks and scarps, which could constitute anti-erosion obstacles.

The creation of large plots in the areas with small slopes (up to 6\%) is considered correct. However, creation the same plots on steep slopes may turn out to be erosive and dangerous to the environmental resources, mainly soil and water.

It was investigated how the decision of surveyors-designers to create a large plot of land in eroded area may influence the occurrence of potential water erosion. The WEPP (Water Erosion Prediction Project) simulation model was used for this purpose. For the comparison of the pre-merge state with the post-merge state, the soil loss and sediment yield were examined. The methodology presented in the author's earlier work [Rybicki 2017] was used, in which, the effect of changing the layout of plots from along to across slope was investigated for the same object (Latyczyn). At the slope scale, the soil loss means the detachment and movement of topsoil by flowing water, while the sediment yield means the amount of material eroded from the land surface by runoff and delivered to a channel or a stream system [Singh et al. 2011]. Moreover, in order to compare the influence of different arrangement of scarps on the slope on the intensity of erosion, the tests were carried out along two sections, i.e. s.1 and s.2 (Fig. 1). In both sections, the shape of the slope and its gradient are almost the same, but the location of the scarps before consolidation were different (Fig. 2). On the section s.1, the scarps were located in the upper part (about $35 \mathrm{~m}$ from the road on the plateau) and in the middle part of the slope (about $67 \mathrm{~m}$ from the road on the plateau). On the section s.2, the scarps were located in the middle (about $55 \mathrm{~m}$ from the road on the plateau) and in the lower part of the slope (about $88 \mathrm{~m}$ from the road on the plateau).

The data for the WEPP model, such as mean annual temperature and annual precipitation, were taken from work of Rybicki [2017]. The soil organic matter content is $1.48 \%$ and bulk density of $1.55 \mathrm{Mg} \cdot \mathrm{m}^{-3}$ with $11 \%$ clay content $(<0.002 \mathrm{~mm})$. The land use structure is typical for Roztocze. Arable land constitutes $60 \%$ of the area, grassland 
occupies about $13 \%$ of the area whereas forests and woodlands represent $22 \%$ of total area.

The data on the relief for the state before and after the consolidation were obtained from the DEM, created on the basis of altitude data obtained in the LIDAR technology (license no. DIO.7211.943.2016_PL_N). For the soil loss and sediment yield simulation, winter wheat was used as the main grain crop in this region and alfalfa as the crop with the best soil erosion protection.

\section{RESULTS AND DISCUSSION}

The changes made as a result of consolidation on the slope being the subject of this study seem to have no effect on the erosion risk. Here, in the consolidation project, one large plot with the number 5810 (4.59 ha) was created from 12 smaller plots - see fig. 1. Before the consolidation, all plots had a cross-slope layout and a cross-slope direction of agrotechnical operations. Exactly the same arrangement remained after the merging. The resulting plot begins on the plateau (watershed) and extends down the slope, reaching the edge of the forest. Before the consolidation, there were sodded dirt roads, both on the plateau and on the border of arable land and forest. Moreover, in the case of these roads, no changes were made as a result of consolidation. These roads have not been liquidated and they constitute some kind of anti-erosion obstacles, counteracting the continuous, linear runoff of water down the slope. Thus, the only changes related to the creation of such a large plot of land were liquidated borders of the old plots, including those constituting the sodded scarps.

The results of the soil loss and sediment yield simulation for the state before and after

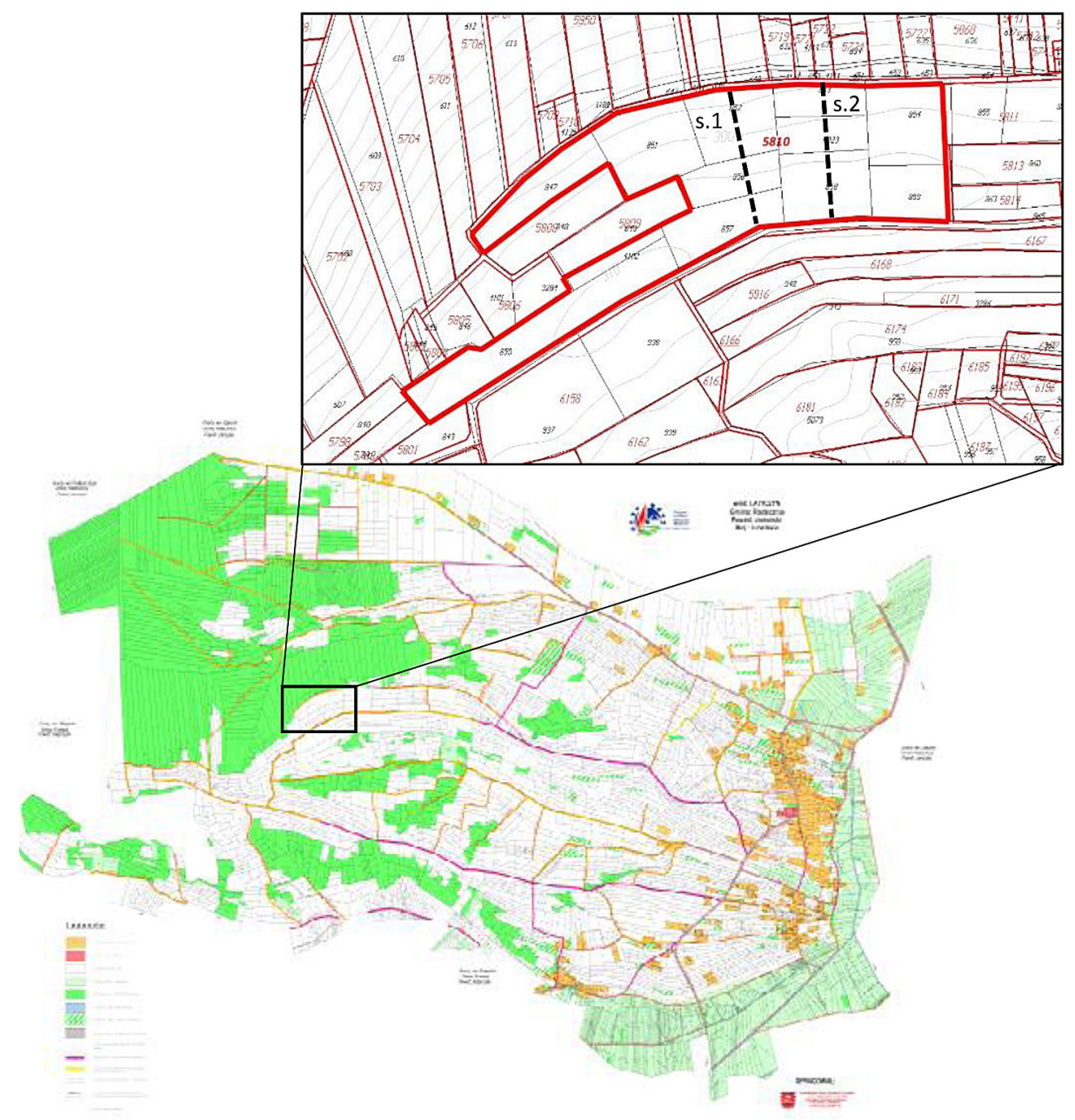

Figure 1. Location of the study area and examined sections of the slope. Own elaboration based on a map of assumption for the project of land consolidation made by the Provincial Bureau of Surveying in Lublin

Notation: s. 1 - section 1; s. 2 -section 2 
consolidation on the examined slope (sections) are shown in Figure 2 and summarized in Table 1.

When the simulated crop is winter wheat, the expected annual soil losses before consolidation, on the slope with the scarps located in the upper and middle part of it (s.1), amounted to $3.71 \mathrm{~kg} \cdot \mathrm{m}^{-2}$, while on the slope with scarps in the middle and lower parts (s.2), the annual soil losses were slightly lower and amounted to $3.25 \mathrm{~kg} \cdot \mathrm{m}^{-2}$. At the same time, the outflow of soil outside the slope during the year amounted to $34.88 \mathrm{Mg} \cdot \mathrm{ha}^{-1}$ and $30.91 \mathrm{Mg} \cdot \mathrm{ha}^{-1}$, respectively. It means that the soil losses on the slope s. 2 were lower than on the slope s. 1 by $12.4 \%$ and the outflow of soil outside the slope was lower by $11.4 \%$. This proves that better protection against erosion is provided by the arrangement of scarps in the middle and bottom of the slope, especially if the top of the slope has a slight gradient. This is also confirmed by the results of the erosion simulation for the alfalfa cultivation, where the differences between both slopes are similar. However, it should be noted that the simulated amount of erosion damage to the alfalfa cultivation, compared to the cultivation of winter wheat, is approximately $30 \%$ lower, which proves that alfalfa protects the soil against erosion better than wheat.

A completely different, dangerous situation is presented by the simulation results for the state after consolidation. After removing the sodded scarps, despite the unchanged cross-slope direction of cultivation, the predicted annual soil loss for the winter wheat cultivation increased to $190.32 \mathrm{~kg} \cdot \mathrm{m}^{-2}$ on $\mathrm{s} .1$ and to $183.17 \mathrm{~kg} \cdot \mathrm{m}^{-2}$ on s.2. The annual sediment yield values increased to 894.50 and $860.92 \mathrm{Mg} \cdot \mathrm{ha}^{-1}$, respectively. This means that the erosion losses, in comparison to the state before the consolidation, increased many times, and the small differences between both sections (also in the case of alfalfa - Table 1) confirm only slight differences in the shape and decline of the examined fragments of the slopes after removing the scarps. When analyzing the observed increase in erosion risk, it should be stated that several reasons are responsible for this state. First of all, this slope is characterized by a significant decline, exceeding $18 \%$ in its lower parts. According to the agrotechnical recommendations for eroded areas [Rybicki 2006], slopes steeper than $15 \%$ should be excluded from the traditional plow cultivation and designated for other development, for example for afforestation. Such method of management would protect the soil against further degradation. In the case of plow management, such large erosion is also caused by too wide a plot cultivated transversely. Before the consolidation, when there were scarps, the slope was divided into three sections, with a width of about 30 to $60 \mathrm{~m}$. After consolidation, the created plot has a width exceeding $130 \mathrm{~m}$. According to Ziemnicki [1967], the width of the cross-slope fields over $100 \mathrm{~m}$, even at a $5 \%$ slope, may be too large to counteract erosion. With a slope exceeding $15 \%$, the same author recommends that the planned plots should be no more than $30 \mathrm{~m}$ wide. Therefore, when assessing the situation on the examined slope, it should be stated that the benefits of the transverse arrangement and the transverse cultivation have disappeared. The water runoff and the resulting erosion are almost like in the case of longitudinal cultivation.

Moreover, the scarps existed before the consolidation, with a height locally exceeding $2 \mathrm{~m}$ (Fig. 2), apart from dividing the slope into narrower fields, caused that the transverse gradient of the slope (terrace shelves) was smaller. According to the studies by Ahmad et al. [2006], on a terraced slope, the speed of the flowing water is much slower; therefore the erosion caused by it is also lower.

The scarps were also covered with turf. The turf protects the soil very well against washing

Table 1. Predicted amounts of soil loss and sediment yield under different scenarios of slope management

\begin{tabular}{|c|c|c|}
\hline The way of land developing & $\begin{array}{c}\text { Average annual soil loss } \\
\mathrm{kg} \cdot \mathrm{m}^{-2}\end{array}$ & $\begin{array}{l}\text { Average annual sediment yield } \\
\mathrm{Mg} \cdot \mathrm{ha}^{-1}\end{array}$ \\
\hline \multicolumn{3}{|l|}{ Type of crop - Winter wheat } \\
\hline s.1 before consolidation & 3.71 & 34.88 \\
\hline s. 1 after consolidation & 190.32 & 894.50 \\
\hline s. 2 before consolidation & 3.25 & 30.91 \\
\hline s. 2 after consolidation & 183.17 & 860.92 \\
\hline \multicolumn{3}{|l|}{ Type of crop - Alfalfa } \\
\hline s.1 before consolidation & 1.23 & 11.51 \\
\hline s. 1 after consolidation & 73.42 & 345.09 \\
\hline s. 2 before consolidation & 1.07 & 10.20 \\
\hline s. 2 after consolidation & 70.82 & 332.86 \\
\hline
\end{tabular}



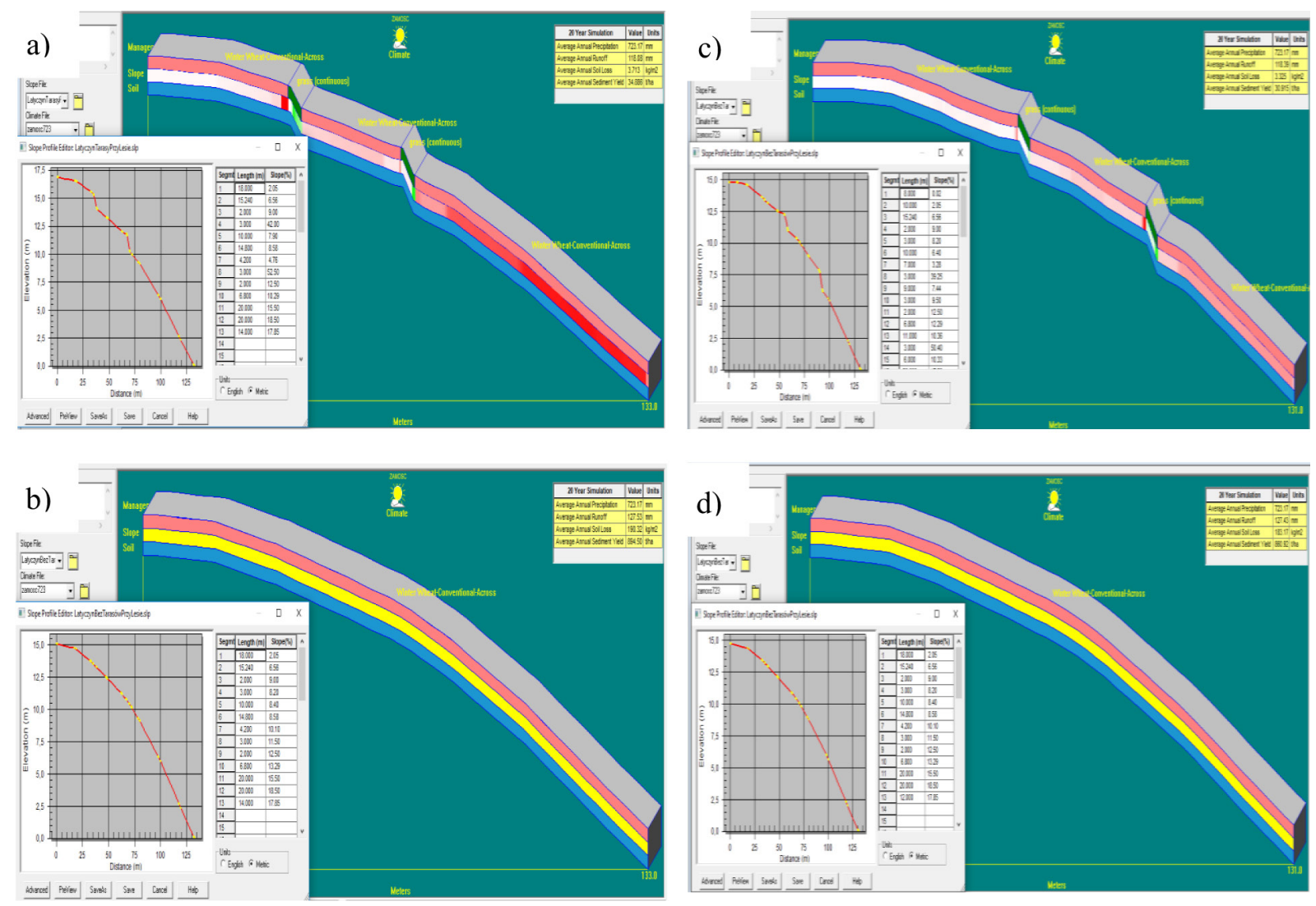

Figure 2. WEPP model window - simulation of erosive soil losses on the examined slope for winter wheat cultivation: a) section s.1, state before consolidation, b) section s.1, state after consolidation,

c) section s.2, state before consolidation, d) section s.2, state after consolidation;

Source: own elaboration. Markings of the section as in figure 1.

caused by flowing water from spring thaws and heavy rains [Konečná et al. 2011; Liu et al. 2013]

Accurate field observations show that apart from the disadvantages of the adopted solution in the consolidation project, there are also advantages. In addition to transverse balks and scarps, before the consolidation, there were also those along the slope, dividing long bands of fields into smaller, short plots. As a result of plowing the end of the field along that boundary strip, local, longitudinal land depressions were created (plow cultivation causes a strong soil displacement and can shape the relief [Govers et al. 1994; Rybicki et al. 2016]). Such places allowed for the concentration of the runoff rainwater, causing groove erosion. Moreover, the bounds located along the slopes constitute a serious erosive hazard and are not recommended in the proper organization of eroded areas [Ziemnicki 1967]. Liquidation of such longitudinal bounds by consolidation should eliminate the problem of linear erosion. Despite the carried out reclamation (liquidation of all boundaries inside the plot), slight depressions of the land still exist, which cause that locally, even under the conditions of cross-slope cultivation, linear erosion is observed (Photo 1a). It should be assumed that with the passage of time during cultivation, these depressions will be leveled out; thus, the concentrated water runoff will be gradually eliminated.

In addition, field observations have also shown that the accumulation of water in larger streams along the furrows and erosion on arable land, in the case of the study area, are not the only problems. Exactly on the extension of the runoff line, just beyond the forest line (Photo 1a), erosive indentation was formed, leading up to the axis of the main ravine (Photo $1 \mathrm{~b}$ ). The concentrated runoff of rainwater from the adjacent field is responsible for its formation. Therefore, the elimination of longitudinal furrows, contributing to a partial elimination of the erosion center on arable lands, will reduce the amount of concentrated water runoff directly reaching the erosion indentations, limiting their further development.

The conducted research confirmed the thesis known from the literature [Ziemnicki 1967; Józefaciuk et al. 1991; 1999; Bożek et al. 2016] 

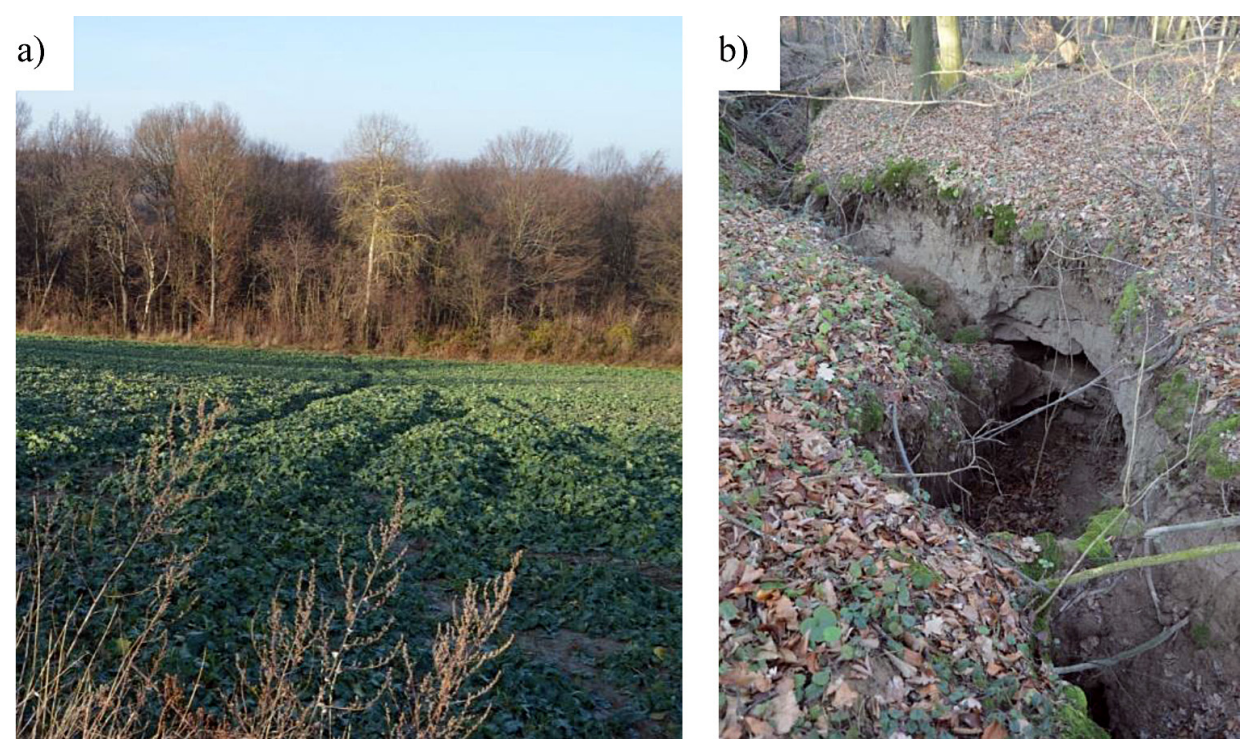

Photo 1. Linear erosion: a) on arable land - slight depression of the land in the place of the longitudinal balk existing before consolidation; b) on wooded ground - erosive indentation formed on the extension of the water runoff line from arable land; Photo: $R$. Rybicki

that one of the most important recommendations for consolidation in eroded areas is to design fields in such a way as to enable the cross-slope cultivation. Nevertheless, it may not be enough. In order to protect the soil from degradation as much as possible, the existing bounds and transverse scarps should be kept intact. In the case of designing new plots of land, and the related design of new borders (in particular the transverse ones), these borders should be absolutely strengthened by turf or bush, which was confirmed by previous studies [Rybicki 2017]. In the case of the analyzed slope, it should be stated that the conducted land consolidation and the related removal of sodded balks and scarps contributed to the acceleration of soil erosion by transforming the deposition areas into the areas generating sediments. The same conclusions were drawn from a study by Chartin et al. [2013] in France. In order to strengthen the anti-erosion effect of the cross-slope cultivation, without increasing the difficulties in carrying out of the agrotechnical measures, it is necessary to restore the sodded scarps existed before the consolidation, located crosswise to the slope (along the plot). As the simulation results show, for the tested slope, these should be scarps in the middle and lower parts of the slope, in the place of the highest inclination. The results of the studies by Xue et al. [2011] and Zhang et al. [2008] prove that in such cases, in addition to reducing erosion, one should also expect an improvement in the soil quality and an increase in the yield of cultivated plants.

\section{CONCLUSIONS}

1. The cross-slope arrangement of arable land and the cross-slope direction of agrotechnical measures are an important element of the land protection strategy against the water erosion.

2. Designing large (wide) plots on slopes during land consolidation may result in the need of liquidating the previously existing balks and transverse scarps.

3. On the slope under study, as a result of designing a plot of land with a width of up to $130 \mathrm{~m}$ and the removing of two sodded scarps in the upper and middle part of the slope, the expected average annual soil loss (in the case of winter wheat cultivation) increased from 3.71 to $190.32 \mathrm{~kg} \cdot \mathrm{m}^{-2}$, and the average annual sediment yield increased from 34.88 to $894.50 \mathrm{Mg} \cdot \mathrm{ha}^{-1}$.

4. Designing the same plot and the related removing of two sodded scarps in the middle and lower part of the slope increased the average annual soil loss (in the case of winter wheat cultivation) from 3.25 to $183.17 \mathrm{~kg} \cdot \mathrm{m}^{-2}$, while the average annual sediment yield increased from 30.91 to $860.92 \mathrm{Mg} \mathrm{ha}^{-1}$.

5. The predicted erosion losses in the case of the simulated alfalfa cultivation compared to winter wheat were lower by about three times, while the differences between the two variants of the scarps distribution on the slope were similar to that in the cultivation of winter wheat. 
6. The average annual soil loss before consolidation was lower by $12.4-13.0 \%$ on the s. 2 slope than on the s. 1 slope. Average annual sediment yield was lower by $11.4 \%$ respectively.

7. After consolidation, the values of average annual soil loss and average annual sediment yield for the two variants of scarps placement differed by no more than $3.7 \%$.

8. The smallest erosive soil losses occurred before consolidation, when the scarps were located in the middle and lower part of the slope.

9. Elimination of longitudinal balks as a result of land consolidation limited the focuses of linear erosion, while the previously formed depressions of the land require careful reclamation in order to reduce the possibility of concentration of rainwater runoff, causing linear erosion, even with transverse development and cultivation or afforestation of the land.

10. On the slope under study, in order to enhance the anti-erosion effect of cross-slope cultivation, the sodded scarps existing before the consolidation should be reconstructed. These scarps should be located in the middle and lower part of the slope, in the places of the highest inclination.

\section{Acknowledgements}

Publication is funded by the Polish National Agency for Academic Exchange under the International Academic Partnerships Programme from the project „Organization of the 9th International Scientific and Technical Conference entitled Environmental Engineering, Photogrammetry, Geoinformatics - Modern Technologies and Development Perspectives".

\section{REFERENCES}

1. Ahmad H. Abu Hammad, Børresen T., Haugen L.E. 2006. Effects of rain characteristics and terracing on runoff and erosion under the Mediterranean. Soil \& Tillage Research 87. 39-47

2. Bożek P., Janus J., Taszakowski J., Glowacka A. 2016. Determining Consistency of Tillage Direction with Soil Erosion Protection Requirements as The Element of Decision-Making Process in Planning and Applying Land Consolidation. World Multidisciplinary Earth Sciences Symposium IOP Publishing, IOP Conf. Series: Earth and Environmental Science 44. 1-6.

3. Bronstert A., Vollmer S., Ihringen J. 1995. A review of the impact of land consolidation on runoff production and flooding in Germany. Physics and chemistry of the earth. Vol 20, Issues 3-4. 321-329.

4. Bucher B., Demuth S. 1986. Vergleichende Wasserbilanz eines flurbereinigten und eines nicht flurbereinigten Einzugsgebietes im Ostkaiserstuhl für den Zeitraum 1977-1980. Weiterbildung Wasser- und Kulturbau -Wassermengenwirtschaft, 19, Stuttgart. 25-35.

5. Chartin C.,Evrard, O., Salvador-Blanes S., Hinschberger F., Van Oost K., Lefèvre I., Daroussin J., Macaire J. 2013. Quantifying and modelling the impact of land consolidation and field borders on soil redistribution in agricultural landscapes (1954-2009). Catena, Vol. 110. 184-195.

6. Journal of Laws 11, item 80, as amended changes. Act of March 26, 1982 on the consolidation and exchange of land.

7. Evrard O., Nord G., Cerdan O., Souchère V., Le Bissonnaise Y., Bonté P. 2010. Modelling the impact of land use change and rainfall seasonality on sediment export from an agricultural catchment of the northwestern European loess belt. Agriculture, Ecosystems and Environment 138. 83-94.

8. Govers G., Vandaele K., Desmet P., Poesen J., Bunte K. 1994. The role of tillage in soil redistribution on hillslopes. European Journal of Soil Science. 45. 469-478.

9. Jabłoński T. 2012. Assumptions for the project of consolidation Latyczyn precinct. Provincial Bureau of Surveying in Lublin. Typescript. (In Polish)

10. Józefaciuk Cz., Woch F., Jadczyszyn J. 1991. The specificity of consolidations in upland areas. Zesz. Nauk. AR w Krakowie, 256(30). 15-21. (In Polish)

11. Józefaciuk A., Józefaciuk Cz., Nowocień E., Woch F. 1999. Programming the protection of soils against erosion as an element of shaping the eco-development of the highlands region of Central and Eastern Poland. Pam. Puławski - prace IUNG Puławy. 119. 7-17. (In Polish)

12. Kadlec V., Žížala D., Novotný I., Heřmanovská D., Kapička J., Tippl M. 2014. Land consolidations as an effective instrument in soil conservation. Ekológia (Bratislava), Vol. 33, No. 2. 188-200.

13. Kondracki J. 2002. Regional geography of Poland. Wydawnictwo Naukowe PWN, Warszawa. (In Polish)

14. Konečná J., Podhrázská J., Karásek P., Dumbrovský M. 2011. Soil and water conservation within the framework of land consolidation process in the Hubenov Cadastre (Czech Republic). Maravian Geographical Reports, 3, Vol. 19. 8-14.

15. Koreleski K., 1991: Surface erosion and its agricultural and organizational aspects on the example of mountain villages. Zesz. Nauk. AR w Krakowie, 256, cz. II. 23-28. (In Polish) 
16. Leń P., Król Ż. 2016. Analysis of economic and environmental effects of land consolidation on the example of Hucisko village. Journal of Ecological Engineering, 17(5). 232-239.

17. Lisec A., Pintar M. 2005. Conservation of natural ecosystems by land consolidation in the rural landscape. Acta agriculturae Slovenica, 85(1), 73-82.

18. Liu S.L., Dong Y.H., Li D., Liu Q., Wang J., Zhang X.L. 2013. Effects of different terrace protection measures in a sloping land consolidation project targeting soil erosion at the slope scale. Ecological Engineering 53. 46-53.

19. Moravcova J., Koupilova M., Pavliček T., Zemek F., Kvitek T., Pečenka J. 2017. Analysis of land consolidation projects and their impact on land use change, landscape structure, and agricultural land resource protection: case studies of Pilsen-South and Pilsen-North (Czech Republic). Landscape Ecol Eng, Vol. 13, 1-13.

20. Nowocień 2006. Anti-erosion melioration in the process of rural areas arranging. In: Comprehensive consolidation of agricultural and forest land and its impact on the environment. Ed. F. Woch. Mat. szkol. Nr 93. IUNG-PIB Puławy. 156-159. (In Polish)

21. Pašakarnis G., Maliene V. 2010. Towards sustainable rural development in Central and Eastern Europe: Applying land consolidation. Land Use Policy 27. 545-549.

22. Podhrázská J., Jeníčková H. 2011. Processing of proposals for land consolidation in the foothills conditions. Acta Universitatis Agriculturae et Silviculturae Mendelianae Brunensis. Vol. LIX(22), No 1. 199-209.

23. Przegon W. 2007. Environmental protection in land consolidation projects. Czasopismo Techniczne Nr 7, Wydawnictwo Politechniki Krakowskiej. 269-275. (In Polish)

24. Rybicki R. 2006. Development of land at risk of erosion in the light of sustainable agriculture. Inżynieria Rolnicza. Nr 6. 231-239. (In Polish)

25. Rybicki R., Obroślak R., Mazur A., Marzec M. 2016. Assessment of tillage translocation and tillage erosion on loess slope by contour mouldboard tillage. Journal of Ecological Engineering, 17(5), 247-253.

26. Rybicki R. 2017. Evaluation of the effects of land consolidation in the Latyczyn village in terms of land protection against erosion on the slope scale. Journal of Water and Land Development. No. 35. 203-209.

27. Sayilan H. 2014. Importance of land consolidation in the sustainable use of Turkey's rural land resources. Procedia - Social and Behavioral Sciences 120. 248-256.

28. Shuai, Y., Chao-Fu W., Xin-Yue Y., You-Jin L. 2011. The Ecological compensation of land consolidation and its evaluation in hilly area of southwest China. Energy Procedia 5. 1192-1199.

29. Singh R.K., Panda R.K., Satapathy K.K., Ngachan S.V. 2011. Simulation of runoff and sediment yield from a hilly watershed in the eastern Himalaya, India using the WEPP model. Journal of Hydrology., 405(3/4). 261-276.

30. Sobolewska-Mikulska K., Pułecka A. 2007: Land consolidation and land replacement in rural development. Oficyna Wydawnicza Politechniki Warszawskiej, Warszawa. (In Polish)

31. Uiszczak A. 1960. Land consolidation as a factor increasing soil erosion. Czas. Geogr. 31(2), 179-190. (In Polish)

32. Van Dijk T. 2007. Complications for traditional land consolidation in Central Europe. Geoforum 38, 505-511.

33. Woch F. 2006. Perspectives of structural changes in rural areas. In: Comprehensive consolidation of agricultural and forest land and its impact on the environment. Ed. F. Woch. Mat. szkol. Nr 93. IUNGPIB Puławy, 5-22. (In Polish)

34. Woch F., Józefaciuk Cz. 1999. The concept of comprehensive land consolidation in a protected area of varied relief. Pam. Puławski - prace IUNG, 119, 65-81. (In Polish)

35. Xue S., Liu G., Zhang C., Fan L. 2011. Effects of terracing slope cropland on soil quality in Hilly Region of Loess Plateau. Nongye Gongcheng Xuebao/ Transactions of the Chinese Society of Agricultural Engineering, 27(4), 310-316.

36. Zhang J.H., Su Z.A., Liu G.C. 2008. Effects of Terracing and Agroforestry on Soil and Water Loss in Hilly Areas of the Sichuan Basin, China. J. Mt. Sci. $5, .241-248$.

37.Ziemnicki S. 1967. Antierosion meliorations. Warszawa. PWRiL. (In Polish) 